\title{
多数回繰返し水平力を受ける鋼・コンクリート合成柱材の 安定限界軸力の実験的研究 \\ AN EXPERIMENTAL STUDY ON STABILITY LIMIT AXIAL LOAD OF STEEL AND CONCRETE COMPOSITE COLUMNS SUBJECTED TO A LARGE NUMBER OF CYCLIC HORIZONTAL LOADS
}

\author{
倉富 洋*, 堺 純一**, 田中照久***, 河本裕行**** \\ Yo KURATOMI, Junichi SAKAI, Teruhisa TANAKA \\ and Hiroyuki KAWAMOTO
}

\begin{abstract}
In order to investigate stability limit axial load of steel and concrete (SC) composite columns, an experimental work of SC column was carried out under constant axial load and cyclic horizontal load. The experimental results indicated that the stable axial load exists, which is almost observed neither flexural strength degradation nor increase of axial strain. From the experimental results it can be thought SC column showed stable behavior if axial strain at centroid of column section accumulated by cyclic loading did not exceed strain at the compressive strength of concrete confined by encased cruciform steel. In this paper the maximum value of axial load which SC column shows stable behavior was defined as stability limit axial load, and the stability limit axial load was discussed.
\end{abstract}

Keywords: Steel concrete column, Axial load ratio, Steel ratio, Loading test, Elastic-plastic analysis 鉄骨コンクリート柱, 軸力比, 鉄骨比, 載荷実験, 弾塑性解析

1. 序

著者らは鉄骨鉄筋コンクリート (以下 SRC と略記) 断面から鉄筋を 省略し，薄肉鋼管で横補強することで施工の簡素化を目指した鋼コ ンクリート (以下 SC と略記) 合成構造の弾塑性変形性状を調べ, 構造 性能の把握及び定量的な評価法の提案を行っている1) 4)。本柱材の 特徴として，1) 本柱材の鋼管は柱頭及び柱脚に隙間を設けることを 想定しており，軸力と曲げを負担しないため薄肉の鋼管を使用でき ること，2) 被りコンクリートをなくし，コンクリートを内蔵十字鉄 骨と薄肉鋼管で横拘束することで，コンクリートの耐力及び勒性を 向上させることができること, が挙げられる。これまでの研究から， $\mathrm{SC}$ 柱材は幅厚比 100 程度の非常に薄い鋼管で横補強することによっ て, 高軸力下でも安定した挙動を示すことが分かっている1) 3)。 近年の建築物では, 空間の自由度を確保するため, 柱断面の縮小 化やスパン拡大が構造的に求められている。しかしながら，例えば 高層建築物の低層部等の大きな軸力を受ける柱材に要求される性能 として, 軸力を保持した状態で十分な変形能力を有する必要がある。 一般的に柱材は負担軸力が大きくなると変形性能が低下寸るが，SC 柱材は高軸力下でも優れた変形能力を示寸ため, 上述した意匠上の 要求にも応えられる柱材であるといえる。そこで $\mathrm{SC}$ 柱材が高軸力下 でも優れた耐震性能を示寸ことに着目し, 合理的な断面設計を行い, かつ建物の鉛直荷重を保持し層崩壊を生じさせないような設計手法 を構築するため, 本柱材が安定した挙動を示す限界の軸力を明らか
にすることは重要な課題である。本研究では, 本柱材が安定した挙 動を示す軸力の最大值を安定限界軸力と呼称し, その定義について

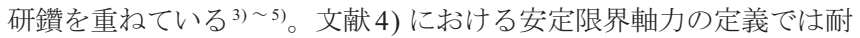
力低下に主眼をおいて解析的に検討したが，柱材の構造性能を評価 する上で, 軸歪の累積はコンクリートの破壊を招くため, 耐力のみ ならず軸歪も厳密に考慮すべきであると考えた。文献 6) 〜9) で鉄筋 コンクリート (以下 RC と略記) 柱材, SRC 柱材の安定限界軸力につい て実験及び解析的に調べられているが，本柱材は内蔵鉄骨に十字鉄 骨を用い，薄肉鋼管によって横補強している点で RC 柱材や SRC 柱材 とは異なる構造性能を示すことから, 本柱材の安定限界軸力を検討 する必要がある。また, 高層建築物の低層部での側柱では大きな変 動軸力を受けるが，変動軸力の最大の圧縮軸力を一定軸力として載 荷した繰返し水平力を受ける柱材の方が変動軸力を受ける柱材と比 べ軸歪の累積は大きい10), 11) ため, 本論では一定軸力下を対象とする。

本論では, 安定限界軸力に影響を与えると考えられる内蔵十字鉄 骨比, コンクリート強度, 軸力比の違いが定変位振幅で繰返し水平 力を受ける SC 柱材の挙動に及ぼす影響を実験的に調べ, 安定限界軸 力について検討することを目的とする。実験の変位振幅は SRC 規準 12) で規定されている制限軸力と比較するために部材角 $1.0 \%$ を主とし, 水平変形量を大きくした部材角 $2.0 \%$ についても検討した。また，著 者らが提案した十字鉄骨によるコンクリートの拘束効果を考慮した 解析手法3) を用いて弾塑性解析を行い, 本実験結果と比較検討した。

\footnotetext{
本論文は文献 5 )に加筆，修正を加えたものである。

* 福岡大学大学院工学研究科 博士後期課程 · 工修

** 福岡大学工学部建築学科 教授・博士(工学)

*** 福岡大学工学部建築学科 助手

**** 福岡建設専門学校 講師.工修
}

Graduate Student, Graduate School of Eng., Fukuoka Univ., M. Eng. Prof., Fac. of Eng., Fukuoka Univ., Dr. Eng.

Assoc. Research, Fac. of Eng., Dept. of Architecture, Fukuoka Univ., B. Eng. Lecturer, Fukuoka College of Civil. Eng. \& Arch., M. Eng. 


\section{2. 実験概要}

\section{1 試験体}

安定限界軸力を実験的に検討するため, 柱断面 $200 \mathrm{~mm}$ x $200 \mathrm{~mm}$ (実 測值 $195 \mathrm{~mm} \times 195 \mathrm{~mm}$ )，せん断スパン比 2 を有する試験体 (図 1 参照) を 8 体製作し，一定軸力下で正負交番繰返し水平力を載荷する柱材 の実験を行った。試験体を横補強した鋼管は，コンクリートを拘束 するためだけであるものとし，軸力と曲げモーメントを負担させな いため柱頭と柱脚部に $10 \mathrm{~mm}$ の隙間を設けた。また，上下スタブに はD10の主筋とD6 の横補強筋を用いた鉄筋籠を挿入して補強した。

試験体一覧を表 1 に示す。実験変数は内蔵十字鉄骨比 $s p\left(={ }_{s} A / A,{ }_{s} A\right.$ : 内蔵十字鉄骨断面積, $A: \mathrm{SC}$ 柱断面積, $A=A+A, A$ : コンクリート断面 積, $A$ : 鉄骨断面積), コンクリート強度, 軸力比 $n\left(=N V_{s c} N_{u}, N\right.$ : 作用軸 力, ${ }_{s c} N_{u}$ : $\mathrm{SC}$ 柱断面の圧縮而扵力, ${ }_{{ }_{c} c} N_{u}=A \cdot{ }_{c} \sigma_{B}+{ }_{s} A \cdot{ }_{\mathrm{s}} \sigma_{\mathrm{y}}, \sigma_{B}$ : コンクリートの 圧縮強度, $\sigma_{\mathrm{s}} \sigma_{\mathrm{y}}$ : 鉄骨の降伏点），変位振幅（部材角 $R=1.0 \%, 2.0 \%$ ）であ
る。SC 柱材はコンクリートを拘束することで耐力低下が抑えられる ことから効果的に高強度コンクリートを使用できるという特徽を考 慮し， $60 \mathrm{~N} / \mathrm{mm}^{2}$ 級の高強度コンクリートに主眼をおいた実験計画と している。また，本実験では製作上の都合により鋼管板厚を $2.3 \mathrm{~mm}$ (鋼管幅厚比 $B / t=87, B$ : 柱断面幅， $t$ : 鋼管板厚）に統一している。

十字鉄骨はSS400 材で，ウェブに $4.5 \mathrm{~mm}$ 厚， $2.3 \mathrm{~mm}$ 厚，フランジに $6 \mathrm{~mm}$ 厚, $2.3 \mathrm{~mm}$ 厚の鋼板より切り出した鋼片を溶接して形鋼を製作 している。また，薄肉鋼管は $2.3 \mathrm{~mm}$ 厚の SS400 材を使用し，断面の 4 隅を溶接することにより製作した（図 1 参照）。表 2 に鋼材の機械的 性質を，表 1 にコンクリートの圧縮強度を示寸。なお，コンクリー 卜は最大骨材寸法 $13 \mathrm{~mm}$ で縦打ちで打設した。

\section{2 載荷方法}

載荷装置を図 2 に示す。載荷は, $2000 \mathrm{kN}$ の鉛直力載荷装置によっ て所定の軸力を載荷した後，一定に保持した状態で $500 \mathrm{kN}$ の水平力

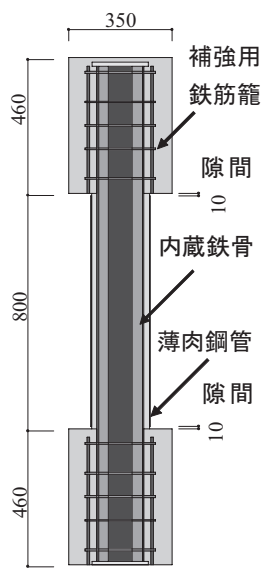

図 $1 \mathrm{SC}$ 柱試験体

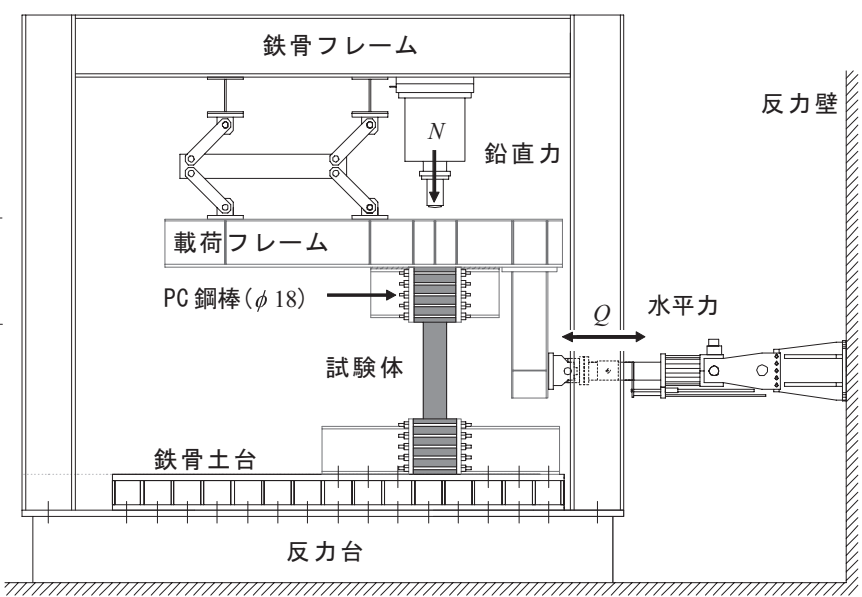

図 2 載荷装置

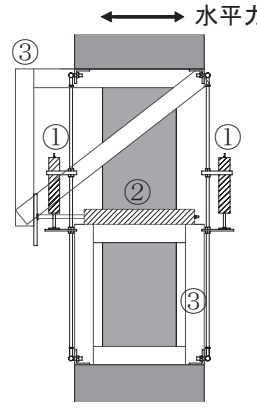

(1)：軸方向変位計

(2) : 水平方向変位計

(3)：変位計フレーム

図 3 変位計取付図

表 1 試験体一覧

\begin{tabular}{|c|c|c|c|c|c|c|c|c|}
\hline \multirow{2}{*}{ 試験体名 } & \multirow{2}{*}{$\begin{array}{c}{ }_{c} \sigma_{B} \\
\left(\mathrm{~N} / \mathrm{mm}^{2}\right)\end{array}$} & \multirow{2}{*}{ 軸力比 $n$} & \multirow{2}{*}{$\begin{array}{c}\text { 載荷軸力 } \\
N(\mathrm{kN})\end{array}$} & \multirow{2}{*}{$\begin{array}{c}\text { 内蔵十字鉄骨寸法 } \\
\text { ( )内は鉄骨比 }\end{array}$} & \multirow{2}{*}{$\begin{array}{l}\text { 振幅 } \\
R(\%)\end{array}$} & \multicolumn{2}{|c|}{ 薄肉鋼管 } & \multirow{2}{*}{ 備考 } \\
\hline & & & & & & 板厚 $(\mathrm{mm})$ & 幅厚比 & \\
\hline L30-0.45 & 27.9 & 0.45 & 909 & \multirow{7}{*}{$\begin{array}{c}\mathrm{CH}-160 \times 80 \times 4.5 \times 6 \\
(s p=8.1 \%)\end{array}$} & \multirow{12}{*}{1.0} & \multirow{14}{*}{2.3} & \multirow{14}{*}{87} & \\
\hline L30-0.55 & 29.3 & 0.55 & 1137 & & & & & \\
\hline L30-0.70* & 27.9 & 0.70 & 1412 & & & & & L30-0.45の実験終了後, 再び載荷 \\
\hline L60-0.40 & 54.2 & 0.40 & 1156 & & & & & \\
\hline L60-0.50* & 54.2 & 0.50 & 1444 & & & & & L60-0.40の実験終了後, 再び載荷 \\
\hline L60-0.55 & 54.8 & 0.55 & 1590 & & & & & \\
\hline L60-0.65* & 54.2 & 0.65 & 1872 & & & & & L60-0.50の実験終了後, 再び載荷 \\
\hline S60-0.40 & 57.2 & 0.40 & 949 & \multirow{5}{*}{$\begin{array}{c}\mathrm{CH}-140 \times 50 \times 2.3 \times 2.3 \\
(s p=2.7 \%)\end{array}$} & & & & \\
\hline $\mathrm{S} 60-0.45$ & 54.9 & 0.45 & 1031 & & & & & \\
\hline $\mathrm{S} 60-0.50^{*}$ & 54.9 & 0.50 & 1146 & & & & & S60-0.45の実験終了後, 再び載荷 \\
\hline $\mathrm{S} 60-0.55$ & 55.4 & 0.55 & 1270 & & & & & \\
\hline $\mathrm{S} 60-0.60^{*}$ & 57.2 & 0.60 & 1424 & & & & & S60-0.40の実験終了後, 再び載荷 \\
\hline L30-0.45 II & 40.0 & 0.45 & 1062 & \multirow{2}{*}{$\begin{array}{c}\mathrm{CH}-160 \times 80 \times 4.5 \times 6 \\
\quad(s p=8.1 \%)\end{array}$} & \multirow{2}{*}{2.0} & & & \\
\hline L30-0.65 II * & 40.0 & 0.65 & 1540 & & & & & L30-0.45 II の実験終了後, 再び載荷 \\
\hline
\end{tabular}

*は再載荷した試験体， $\sigma_{B}$ はコンクリート強度をそれぞれを示寸

試験体名凡例

表 2 鋼材の機械的性質

\begin{tabular}{c|c|c|c|c|c|c}
\hline 部材名 & $t(\mathrm{~mm})$ & $\sigma_{y}\left(\mathrm{~N} / \mathrm{mm}^{2}\right)$ & $\sigma_{u}\left(\mathrm{~N} / \mathrm{mm}^{2}\right)$ & $E\left(\mathrm{~N} / \mathrm{mm}^{2}\right)$ & $E l n g .(\%)$ & $Y . R$. \\
\hline 薄肉鋼管, 十字鉄骨 & 2.3 & 335 & 485 & $2.01 \times 10^{5}$ & 33.7 & 0.69 \\
\hline \multirow{2}{*}{ 十字鉄骨 } & 4.5 & 322 & 452 & $2.02 \times 10^{5}$ & 32.4 & 0.71 \\
\cline { 2 - 7 } & 6 & 349 & 473 & $2.00 \times 10^{5}$ & 37.1 & 0.74 \\
\hline
\end{tabular}

$\bar{t}$ : 板厚 $\sigma_{y}$ : 降伏点 $\sigma_{u}$ : 引張強さ $E$ :ヤング係数 Elng. : 伸び率 $Y . R$. : 降伏比

L $30-\underline{0.45}$

丁軸力比 டコンクリート強度

— 内蔵十字鉄骨寸法

L:鉄骨比 $8.1 \%$ S:鉄骨比 $2.7 \%$ 
載荷装置で正負交番繰返し水平力を載荷し, 柱材が逆対称変形状態 になるようにした。また, 載荷フレームと試験体は PC 鋼棒で締め 上げて一体化させた。載荷形式は, 文献 6)，8）を基に部材角 $R=1.0 \%$ 及び $R=2.0 \%$ の定変位振幅で 20 回の正負交番繰返し水平力を与えた。 また, 試験体 L30-0.70* は L30-0.45 の実験終了後に一度軸力を抜き, 再び所定の軸力を載荷して 20 回の繰返し水平力を与えた。同様の手 順で再載荷した試験体は表 1 中に*マークで示している。詳細は表 中の備考を参照されたい。測定は，歪ゲージを柱頭柱脚部の強軸鉄 骨フランジ及び，鋼管に 2 枚ずつ貼付し，鉄骨と鋼管の歪を測定し た。また, 柱材の水平変位及び材軸方向の軸縮みの変形は柱頭及び 柱脚のスタブ部分に変位計フレームを設置し, 測定した (図 3 参照)。

\section{3. 実験結果と考察}

実験結果を表 3 に示す。また, 実験で得られた水平力 $Q^{-}$部材角 $R$ 関係を図 4.1 及び図 4.2 (以下図 4 と略) に, 軸縮み $\delta_{v}$ - 部材角 $R$ 関係 を図 5.1 及び図 5.2 (以下図 5 と略) に，それぞれ示す。再載荷した試 験体については，20 回繰返し水平力を与えた前載荷終了後に軸力を 抜き再度所定の軸力を載荷したところ, 振幅 $R=1.0 \%$ の試験体では残 留変形量が部材角 $R=0.02 \%$ 程度と小さい值であったため, 残留変形 を原点に戻すことをせずに再載荷を行った。変位振幅 $R=2.0 \%$ を含 め, 再載荷した試験体の図 4 , 図 5 の原点は前載荷の原点を表す。図 3 中の点線は鋼材及びコンクリートの材料強度を用いて計算した一 般化累加強度 $M_{p c}$ (表 3 中 $M_{p c l}$ と表記) を柱頭, 柱脚部でそれぞれ発揮 するとして式(1) で求めた塑性崩壊機構形成時の耐力である。また, 同図中の実線は SRC 規準 ${ }^{12)}$ によるコンクリートの低減係数 $\gamma_{U} \gamma_{U}$ を用い て計算した一般化累加強度 (表 3 中 $M_{p c 2}$ と表記) で求めたものである。

$$
Q=\frac{M_{p c}}{L}-\frac{N \delta}{L}
$$

ここで， $L$ : スタブフェイスから反曲点（材長の中間点を想定）ま での距離， $N$ : 柱軸力， $\delta$ : 反曲点での水平変位である。

図 6 に繰返しに伴う曲げ耐力低下率を示寸。縦軸には各除荷点に おけるP $P$ 効果を考慮した柱脚位置での抵抗モーメントを各試験体 の最大曲げモーメントで除した值を, 横軸には繰返し回数をとって いる。また, 図 7 に各除荷点の軸縮夕 $\delta_{v}^{-}$繰返し回数 Cycle 関係を示 す。図中の点線は十字鉄骨内側の鉄骨で拘束されたコンクリートの
圧壊歪 $\varepsilon_{c 0}$ に変形域と弾性域を考慮した材長（詳細は 5.4 項の式(4) 及 び図 10(b) 参照）を掛けて軸変形量に変換した $\delta_{c 0}$ を示す。試験体の条 件によって $\delta_{c 0}$ の值は異なるが, 図中には最も小さい值を記してい る。なお，十字鉄骨で拘束されたコンクリートの強度上昇率 $K$ は文 献3)より算出し, この值を用いて $\varepsilon_{c 0}$ を崎野孫式13) から求めている。

\section{1 崩壊性状}

内蔵鉄骨比の小さい $\mathrm{S} 60-0.60 *$ や $R=2.0 \%$ の振幅を与えた L30-0.65 II *はそれぞれ繰返し回数 19 回目, 7 回目の押し載荷にて柱頭部の横 補強鋼管がスタブに接触し, 鋼管溶接部が破断した（写真1(b) 参照)。 その後, 鋼管がコンクリートを拘束できず, 急激な耐力低下が見ら れたため実験を終了した。写真 1 ( c ) に柱頭部をダイヤモンドカッ ターで切断した断面を示す。十字鉄骨の外側のコンクリートにひび 割れが見られたが，十字鉄骨内のコンクリートにひび割れは見られ なかった。その他の試験体は繰返しに伴う耐力低下及び軸縮みの進 行は見られたが，軸力が保持できないような急激な耐力低下を起こ すことなく載荷を終了した（写真1(a) 参照)。鋼管とスタブの隙間 $10 \mathrm{~mm}$ 区間でコンクリートの軽微なひび割れが生じたが，鋼管の局 部座屈や破断といった不安定現象は見られず, 柱部分は健全であっ た。また，S60-0.60*，L30-0.65 II *を除いて20 回の繰返しで曲げ耐力 の低下はほぼなくなり，一定值を保持した。

\section{2 軸力比の違いによる影響}

図 5 より, 軸力比が大きくなるほど軸縮みが大きくなっている

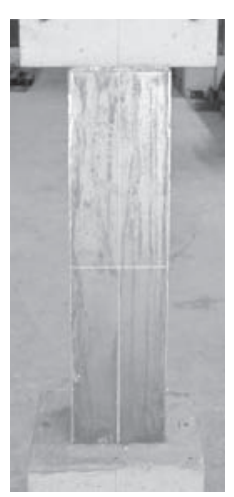

(a) $\mathrm{L} 30-0.55$

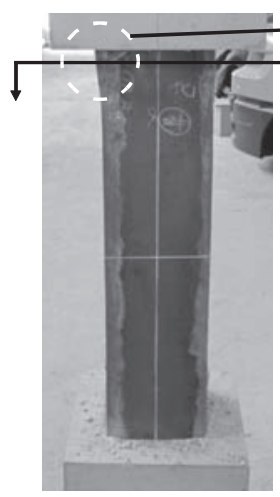

(b) $\mathrm{S} 60-0.60^{*}$
鋼管がスタブに接触
切断

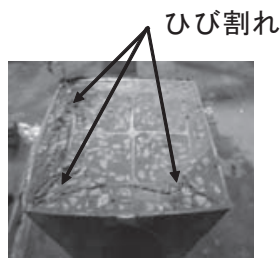

(c) $\mathrm{S} 60-0.60 *$ の 柱頭部切断
写真 1 実験終了後の試験体

表 3 実験結果

\begin{tabular}{|c|c|c|c|c|c|c|c|c|c|c|}
\hline \multirow{3}{*}{ 試験体名 } & \multicolumn{4}{|c|}{ 実験耐力 } & \multicolumn{6}{|c|}{ 計算耐力 } \\
\hline & \multicolumn{2}{|c|}{ 最大曲げ耐力 $\mathrm{M}_{\text {max }}(\mathrm{kNm})$} & \multicolumn{2}{|c|}{ 20回目の曲げ耐力 $\mathrm{M}_{20}(\mathrm{kNm})$} & \multirow{2}{*}{$\begin{array}{c}\mathrm{M}_{\mathrm{pcl} 1} \\
(\mathrm{kNm})\end{array}$} & \multirow{2}{*}{$\begin{array}{c}\mathrm{M}_{\mathrm{pc} 2} \\
(\mathrm{kNm})\end{array}$} & \multirow{2}{*}{$\frac{M_{\text {max }}}{M_{p c 1}}$} & \multirow{2}{*}{$\frac{M_{\max }}{M_{p c 2}}$} & \multirow{2}{*}{$\frac{\mathrm{M}_{20}}{\mathrm{M}_{\mathrm{pc} 1}}$} & \multirow{2}{*}{$\frac{\mathrm{M}_{20}}{\mathrm{M}_{\mathrm{pc} 2}}$} \\
\hline & 正 & 負 & 正 & 負 & & & & & & \\
\hline L30-0.45 & 75.1 & -72.3 & 63.6 & -61.8 & 62.7 & 56.5 & 1.18 & 1.30 & 1.00 & 1.11 \\
\hline L30-0.55 & 74.6 & -80.9 & 65.4 & -69.2 & 59.6 & 51.5 & 1.30 & 1.51 & 1.13 & 1.31 \\
\hline L30-0.70* & 70.5 & -69.8 & 66.3 & -67.5 & 46.5 & 34.5 & 1.51 & 2.03 & 1.44 & 1.94 \\
\hline L60-0.40 & 90.1 & -97.5 & 74.2 & -77.6 & 87.0 & 77.2 & 1.08 & 1.22 & 0.87 & 0.98 \\
\hline L60-0.50* & 79.1 & -85.1 & 74.3 & -76.5 & 84.3 & 71.6 & 0.97 & 1.15 & 0.89 & 1.05 \\
\hline L60-0.55 & 95.8 & -100.7 & 85.0 & -80.9 & 81.8 & 67.2 & 1.20 & 1.46 & 1.01 & 1.23 \\
\hline L60-0.65* & 79.9 & -84.9 & 74.8 & -80.6 & 72.2 & 53.4 & 1.14 & 1.54 & 1.08 & 1.45 \\
\hline S60-0.40 & 71.9 & -72.8 & 57.4 & -59.4 & 63.2 & 54.8 & 1.14 & 1.32 & 0.92 & 1.07 \\
\hline S60-0.45 & 68.1 & -77.6 & 56.7 & -62.6 & 61.1 & 53.0 & 1.19 & 1.37 & 0.98 & 1.13 \\
\hline S60-0.50* & 58.8 & -67.1 & 55.8 & -59.8 & 61.1 & 53.0 & 1.03 & 1.19 & 0.95 & 1.09 \\
\hline S60-0.55 & 78.6 & -78.1 & 56.0 & -59.7 & 61.5 & 53.4 & 1.27 & 1.47 & 0.94 & 1.08 \\
\hline S60-0.60* & 69.1 & -71.4 & $\begin{array}{l}\text { 無 } \\
\end{array}$ & 無 & 63.2 & 54.8 & 1.11 & 1.28 & 無 & 無 \\
\hline L30-0.45 II & 86.3 & -88.0 & 70.7 & -71.7 & 74.4 & 66.6 & 1.17 & 1.31 & 0.96 & 1.07 \\
\hline L30-0.65 II * & 75.9 & -75.9 & 無 & 無 & 65.1 & 52.9 & 1.17 & 1.43 & 無 & 無 \\
\hline
\end{tabular}




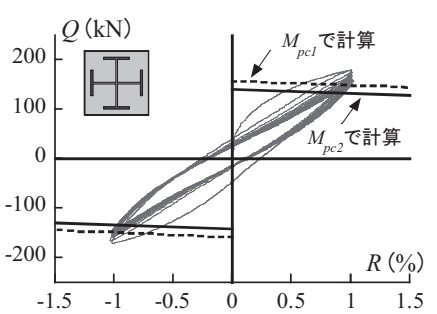

(a) $\mathrm{L} 30-0.45$

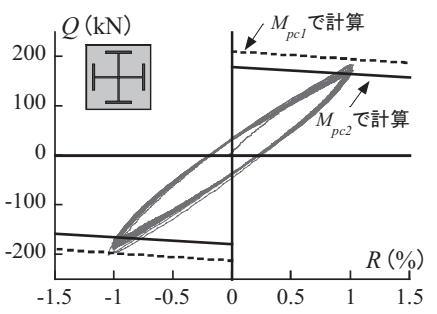

(e) $\mathrm{L} 60-0.50 *$

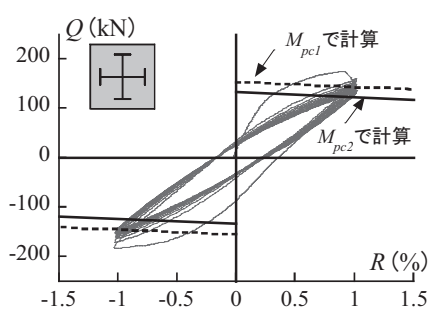

(i) $\mathrm{S} 60-0.45$

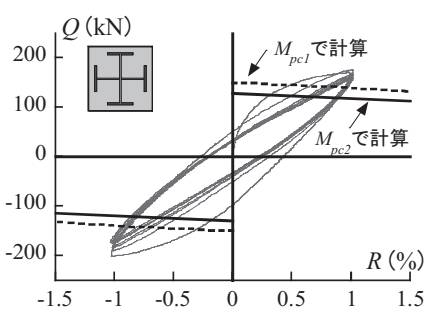

(b) L30-0.55

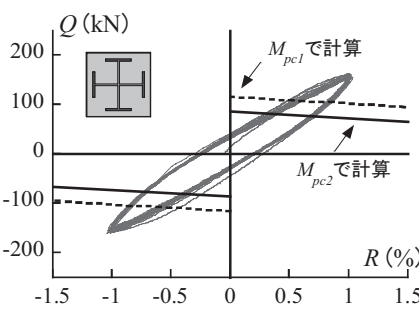

(c) $\mathrm{L} 30-0.70$ *

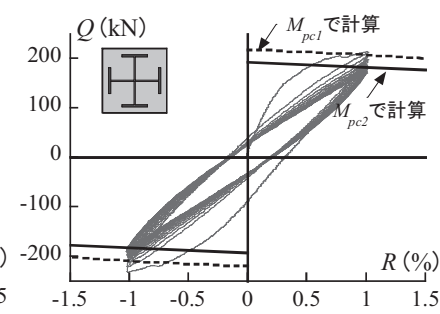

(d) $\mathrm{L} 60-0.40$

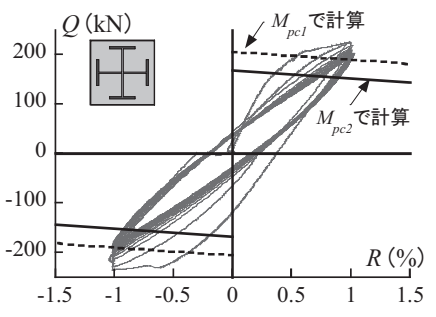

(f) $\mathrm{L} 60-0.55$

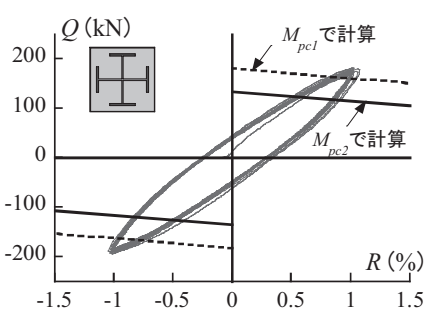

(g) L60-0.65*

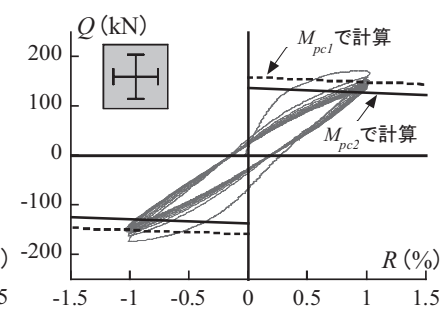

(h) $\mathrm{S} 60-0.40$

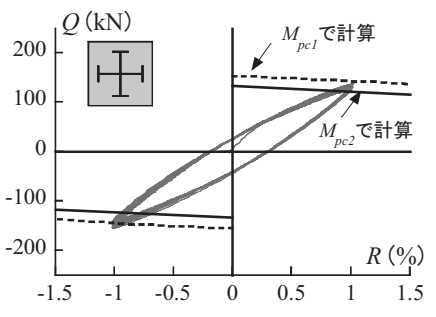

(j) $\mathrm{S} 60-0.50$ *

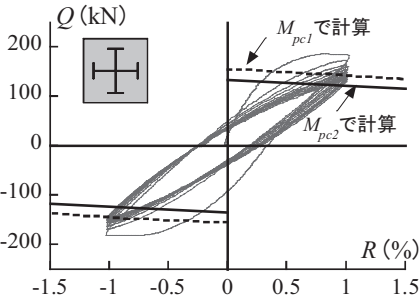

(k) $\mathrm{S} 60-0.55$

図 4.1 水平力 $Q-$ 部材角 $R$ 関係（振幅 $R=1.0 \%$, つづく）

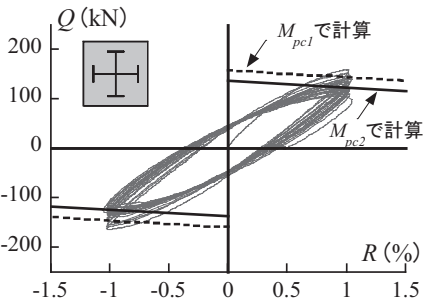

(1) $\mathrm{S} 60-0.60 *$

*は再載荷した試験体を示す

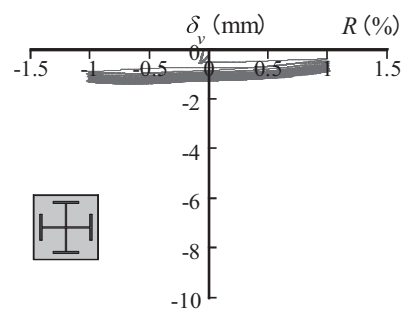

(a) $\mathrm{L} 30-0.45$

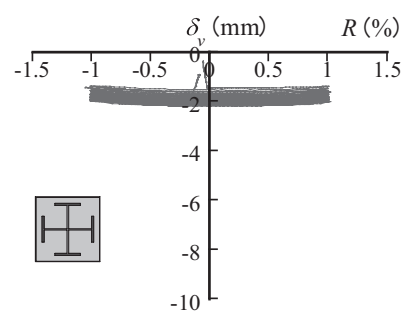

(e) $\mathrm{L} 60-0.50 *$

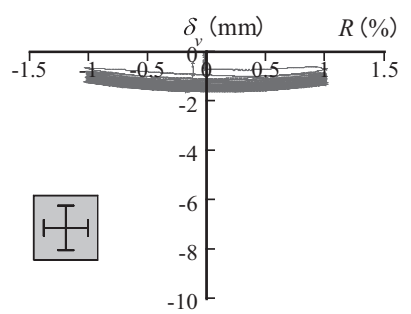

(i) $\mathrm{S} 60-0.45$

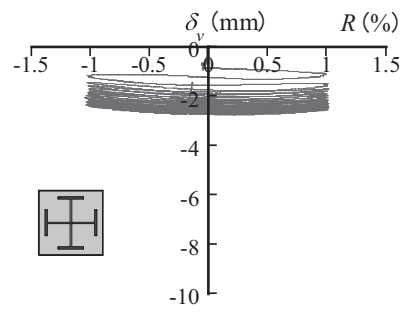

(b) L30-0.55

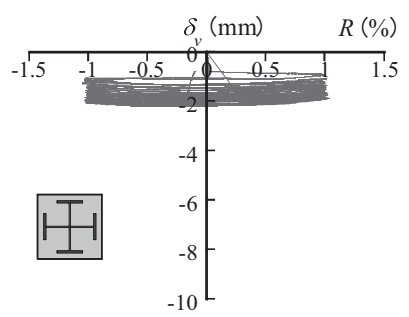

(f) $\mathrm{L} 60-0.55$

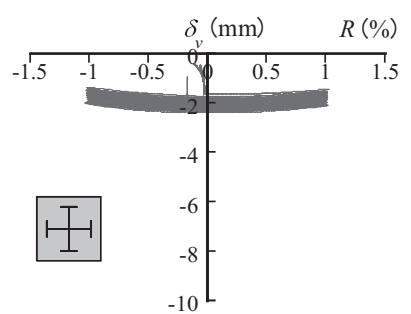

(j) $\mathrm{S} 60-0.50 *$

5.1 軸縮夕 $\delta$ - 部材角 $R$ 関係（振幅 $R=1.0 \%$, つづく

(c) $\mathrm{L} 30-0.70 *$

(g) L60-0.65*

(k) $\mathrm{S} 60-0.55$
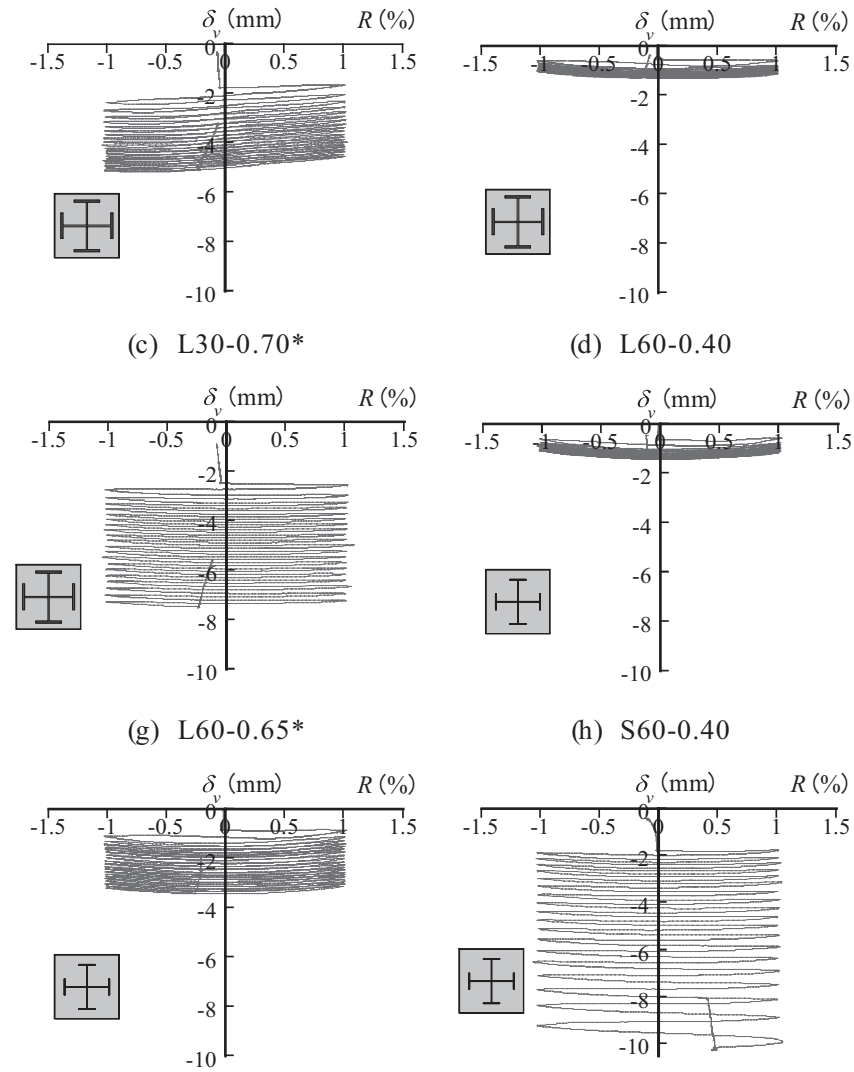

(d) L60-0.40

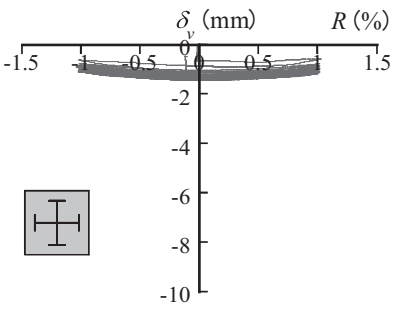

(h) $\mathrm{S} 60-0.40$

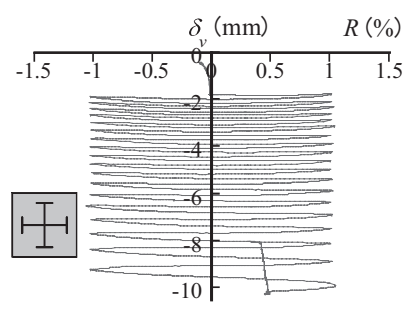

(1) $\mathrm{S} 60-0.60 *$

*は再載荷した試験体を示す 


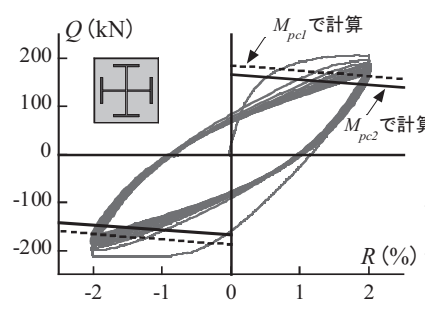

(m) $\mathrm{L} 30-0.45 \mathrm{II}$

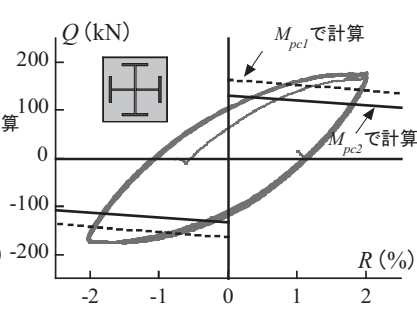

(n) $\mathrm{L} 30-0.65 \mathrm{II} *$

図 4.2 水平力 $Q$ - 部材角 $R$ 関係（振幅 $R=2.0 \%$, つづき）

が，水平力ー部材角関係はエネルギー吸収能力に優れた紡錘形の履 歴ループを示していることが分かる (図 4 参照)。これは，本柱材が $\mathrm{SRC}$ 柱材と比較して被りコンクリートがなく，またコンクリート充 填鋼管構造と比較して鉄骨フランジが局部座屈しにくいことより, 耐力低下が小さくなるためだと考えられる。図 6(a) に軸力比の違い による曲げ耐力低下率を示すが，再載荷した試験体は耐力の低下が 小さいことがわかる。これは，1 サイクル目ではコンクリート及び 鉄骨が無損傷状態であるため水平耐力及び剛性が大きく発揮され， その後繰返し回数の増加により定常ループとなる (例えば図 4 (d) 参 照）。しかしながら，再載荷した試験体ではコンクリートが損傷を受 け，鉄骨が塑性化した状態で載荷を行うため，1 サイクル目から定 常ループとなり（例えば図 4 (e) 参照)，耐力低下があまり見られなく なるためだと考えられる。このことを考慮すると, 軸力比は曲げ耐 力低下率に然程明確な違いを与えず，曲げ耐力の低下より軸縮みの 進行に大きな影響を及ぼすことがわかる。また, 図6(a)より, 部材 角 $R=1.0 \%$ の振幅では軸力比 $n=0.55$ で軸縮みの進行が見られなくなっ たが，部材角 $R=2.0 \%$ の振幅を与えると， $n=0.45$ でも軸縮みが進行し 続け， $n=0.65$ では軸縮みが急激に発散した。このことから，変位振 幅量の違いは柱材の軸縮み挙動に影響を及ぼすことが分かる。なお,

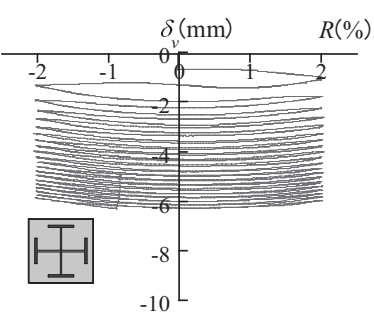

(m) $\quad$ L30-0.45 II

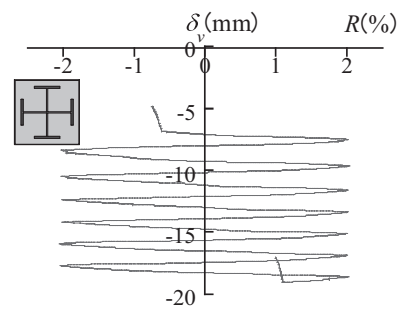

(n) $\mathrm{L} 30-0.65 \mathrm{II} *$
図 5.2 軸縮夕 $\delta$ - 部材角 $R$ 関係（振幅 $R=2.0 \%$, つづき）

変位振幅の違いが柱材の挙動に及ぼす影響については, 弾塑性解析 を行うことで定量的に検討する予定である。

\section{3 内蔵十字鉄骨比の違いによる影響}

図 6(b) に, 鉄骨比の違い(L60 と S60 の比較) が曲げ耐力低下率に及 ぼす影響を示す。軸力比 $n=0.40$ ではあまり違いが見られないが, $n=0.55$ 以上になると鉄骨比が小さいほど耐力低下が大きくなってい ることが分かる。図 7 に示すように, 軸力比 $n=0.55$ において, L シ リーズは十字鉄骨によって拘束されたコンクリートの圧壊歪に達す るまで余裕があるが， S シリーズでは超えている。このことから, 軸 力比が大きくなるほど, 鉄骨比の違いは曲げ耐力の低下及び軸歪の 進行に影響寸ることがわかる。L30-0.70*，L60-0.65*では軸歪が大き く進行しても耐力を保持している(図7(a)，(b) 参照) が，S60-0.60*は 急激な耐力低下が確認できる (図 6(b) 参照)。乙れは, 鉄骨本来の曲 げ性能の違いも当然影響しているが， $\mathrm{S}$ シリーズのような断面が小 さい十字鉄骨を使用すると鉄骨によるコンクリートの拘束領域が減 少するため, コンクリートが多数回の繰り返しによる軸歪の累積に 耐えきれず急激な耐力低下につながったものと考えられる。よって, コンクリートの拘束効果が十分に発揮できるような鉄骨量を内蔵す ることが，高軸力下でも安定した挙動を示す重要な要素であるとい

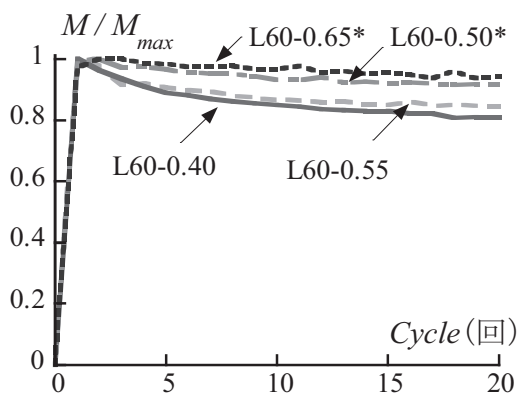

(a) 軸力比の違いによる影響

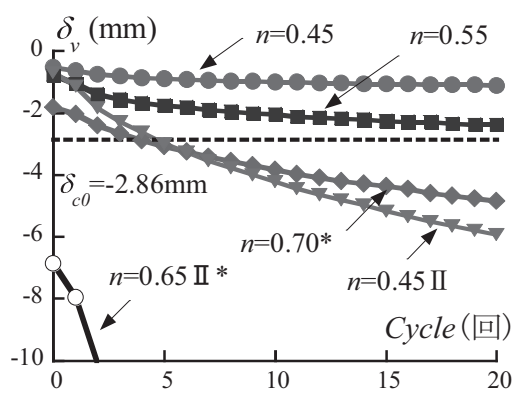

(a) L 30 シリーズ

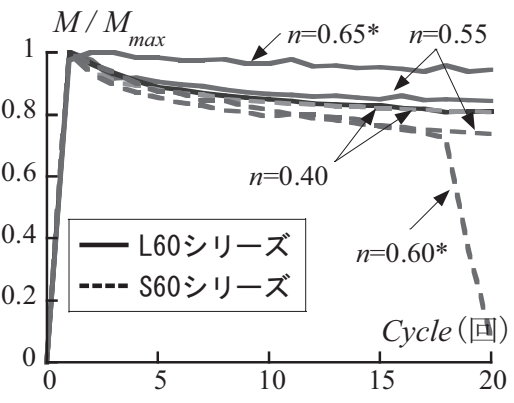

(b) 鉄骨比の違いによる影響 図 6 曲げ耐力低下率

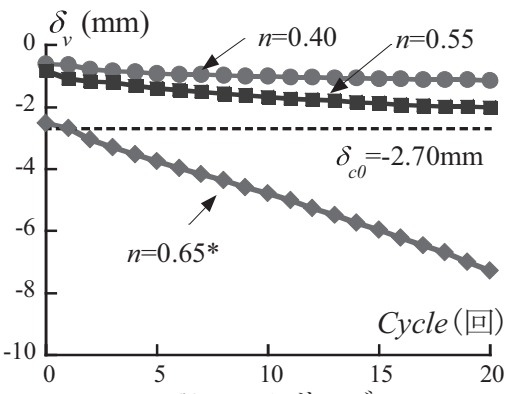

(b) L60 シリーズ

図 7 各除荷点における軸縮み $\delta-$ Cycle 関係

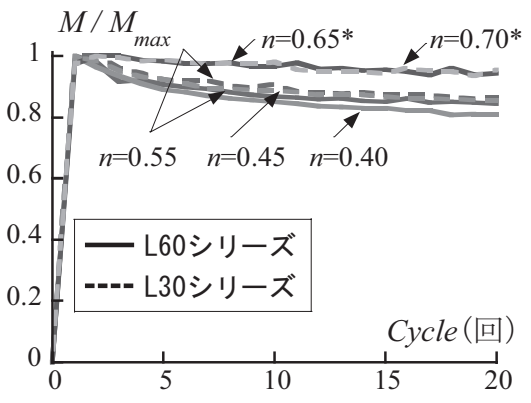

(c) コンクリートの違いによる影響

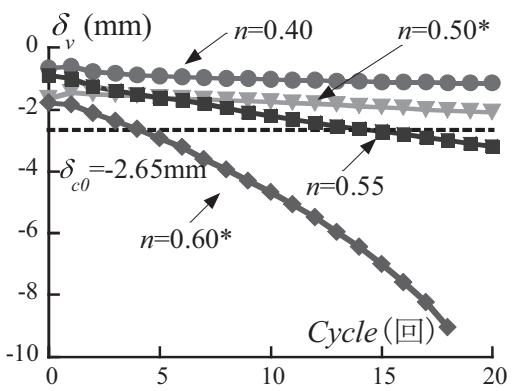

(c) S60 シリーズ 
える。この適切な鉄骨量については, 今後の検討課題である。

\section{4 コンクリート強度の違いによる影響}

図 6(c) に，コンクリート強度の違いが曲げ耐力低下率に及ぼす影 響を示す。何れの軸力比においても，コンクリート強度に拘らず耐 力低下に差異は見られず, 図 5 からも軸縮み量の違いはあまり見ら れない。通常, $\mathrm{RC}$ 柱材や $\mathrm{SRC}$ 柱材に軸力比 $n=0.50$ を超えるような高 軸力下で繰返し水平力を与えると, 被りコンクリートが剥落し急激 な耐力低下及び歪の発散につながる例ネ゙゙6)，8)。一方で本柱材は，コン クリートを薄肉鋼管と内蔵十字鉄骨で拘束することにより，脆性材 料であるコンクリートの勒性を大きく向上させることが可能となる。 それ故, 最大耐力発揮後の耐力低下が大きくなる高強度コンクリー 卜を高軸力下で使用しても優れた変形性能を示寸ものと考えられる。

\section{5 曲げ耐力}

図 8 に軸力 $N^{-}$曲げモーメント $M$ 相関曲線を示す。図中 $\bigcirc$ は $P \Delta$ 効 果を考慮した最大曲げ耐力の正負平均, ○は載荷 20 回目の曲げ耐力 の正負平均である。また， $\triangle, \boldsymbol{\Delta}$ は一度軸力を抜き圧縮軸力を大き くして再び実験を行った試験体を示す。ほとんどの試験体で最大曲 げ耐力は $M_{p c l}$ を発揮し, 20 回繰返し水平力を与えた後でも $M_{p c 2}$ を超 えていることが分かる。コンクリート強度 $30 \mathrm{~N} / \mathrm{mm}^{2}$ の試験体は応力 歪関係においてコンクリートの耐力低下が緩やかになるため, 柱の 曲げ耐力は 20 回載荷後でも $M_{p c 1}$ を上回っている。一方で $60 \mathrm{~N} / \mathrm{mm}^{2}$ の 試験体では耐力低下は $30 \mathrm{~N} / \mathrm{mm}^{2}$ に比較してやや大きいが，ほとんど の試験体で $M_{p c 2}$ を下回ることはなかった。S60-0.65*は19 回目の載荷 で急激な耐力低下が生じ実験を終了しているため, 20 回目の曲げ耐 力は示していない。このことは，鉄骨比が小さい断面 $(s p=2.7 \%)$ を $n=0.60$ のような高軸力下で使用すべきでないことを示唆している。 また, 図 7 中 $\triangle, \boldsymbol{\Delta}$ で示した試験体は耐力低下が他の試験体に比心゙ て小さいことから，20 回の繰返し水平力を与えた後に再び同数回の 水平力を受けても抵抗モーメントの低下が抑えられることがわかる。

以上より, 多数回繰返し水平力を受ける本柱材の最大曲げ耐力は $M_{p c 1}$ で, 20 回目の曲げ耐力はコンクリートが繰返し水平力によって 損傷を受けることを考慮し, コンクリート強度の低減係数 $\gamma_{C}$ を用い た $M_{p c 2}$ で概ね評価できる。

\section{4. 安定限界軸力比}

図 9 に実験結果より各除荷点における軸縮みの増分值 $\Delta \delta(\mathrm{mm})$ に ついて検討した結果の一例を示す。繰返しに伴う増分值はL60-0.65*, S60-0.60* を除いて極めて僅かなものであり, その值は繰返し回数を 増すごとに収束一向かう傾向にある。増分值 $\Delta \delta=0.05 \mathrm{~mm}$ 以下になる と, 図7 の $\delta_{v}$ はほぼ横ばいになっていることがわかる。よって, 増

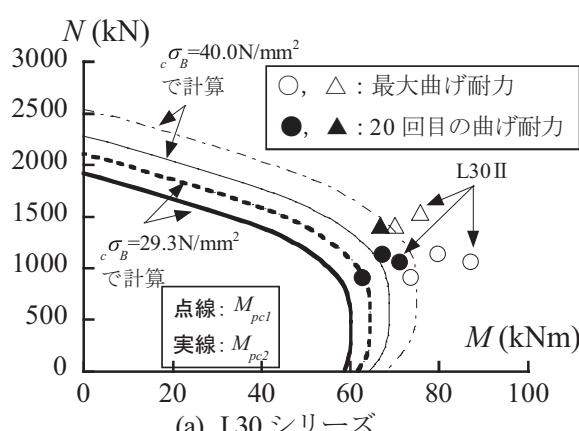

(a) L 30 シリーズ

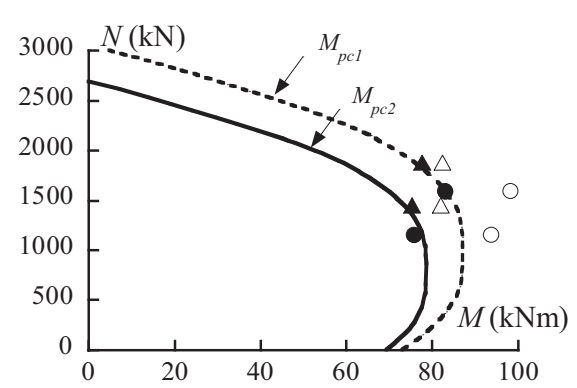

(b) L60 シリーズ
分值自体が極めて微小であることと, 増分が回数を重ねるごとに減 少傾向にあることを考慮して, 増分值が $0.05 \mathrm{~mm}$ 以下になった時点 で 0 とみなし歪の進行は収束したものと考えた。

中心軸歪が発散しない限り, 急激な曲げ耐力の低下につながらな いことは過去の研究6) 9) からも明らかとなっているため, 安定限界 軸力を定義するに従って, 中心軸歪の進行が重要な要素であると考 えることができる。本柱材はコンクリートの拘束力に優れているた め, コンクリートが圧壊歪に達した後でも軸歪が収束することがあ ると考えられる（例えば, 図 9 中の L30-0.70* やS60-0.55, L30-0.45 II の増分值は減少傾向にあり, 繰返し回数を増や寸と収束したとみな せる可能性がある。また, 5 章で述べる弾塑性解析を行うと, 中心 軸歪がコンクリートの圧壊歪を超えて収束する軸力が存在すること を確認している)。しかしながら, 軸歪がコンクリートの圧壊歪を超 えて収束する場合, そのときの軸歪量が過度に大きくなる可能性が あること及び, 平石らの研究7によると大きな地震力を受けた柱材 の軸歪が一度コンクリートの圧壊歪を超えると, 再度中小規模の地 震力を受けた場合でも柱材が脆性的な挙動を示寸危険性があること が報告されている。そこで本柱材の安定限界軸力の定義として, 収 束する軸歪 $\varepsilon_{v}$ が十字鉄骨で拘束されたコンクリートの圧壊歪 $\varepsilon_{c 0}$ を超 えていなければコンクリートが耐力低下域に入らず, 軸力を保持で きないような急激な耐力低下につながることはないものとして, こ のときの最大の軸力を安定限界軸力とした。ここで, 十字鉄骨で拘 束されたコンクリートの圧壊歪を基準としたのは, 十字鉄骨外の鋼 管で拘束されたコンクリートが圧壊歪に達しても, 往々にして圧縮 応力を受ける十字鉄骨内側のコンクリートが健全であれば軸力を保 持でき, 本柱材が安定した挙動を示したためである。

表 4 に増分值 $\Delta \delta$ が $0.05 \mathrm{~mm}$ 以下となる Cycle 数とそのときの収束軸 縮み量 $\delta_{v}$ を示す。図 9 より $\mathrm{L}$ シリーズの試験体は軸力比 $n=0.55$ 以下 で, $\mathrm{S}$ シリーズは $n=0.50$ 以下で増分值 $\Delta \delta=0.05 \mathrm{~mm}$ 以下となるときの軸 変形 $\delta_{v}$ は圧壊軸縮み $\delta_{c 0}$ を超えていないため, 安定であると判断した。 一方で，L30-0.70*及びS60-0.55 では増分值は減少傾向にあるものの, $\Delta \delta=0.05 \mathrm{~mm}$ 以下となることはなく, また L60-0.65* と S60-0.60*, L30-0.45 II では増分值が増加傾向にあり, 収束していない。よって, これら の試験体は不安定と判断した。

以上より, 本論の定義に基づいた変位振幅 $R=1.0 \%$ での各条件下に おける安定限界軸力比は, L $30, \mathrm{~L} 60$ シリーズは共に $n=0.55$ 程度, $\mathrm{S} 60$ シリーズは $n=0.45$ 程度であった。また, 表 4 中に現行の SRC 規準 9 に 規定されている制限軸力 ( コンクリートの圧縮耐力の $1 / 3$ と鉄骨の圧 縮耐力の $2 / 3$ の和）を柱材の断面耐力で除した值を示している。L30, L60, S60 の三条件とも安定限界軸力比は制限軸力を超えていること

図 8 実験曲げ耐力と一般化累加強度

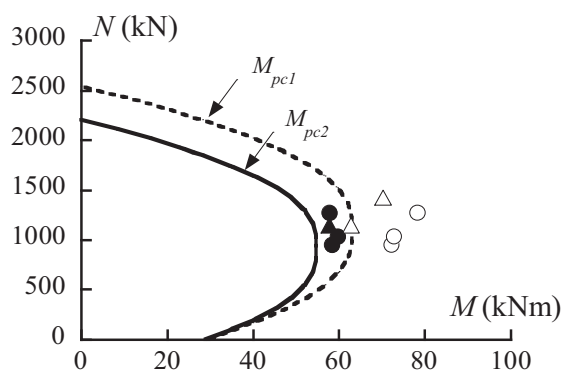

(c) $\mathrm{S} 60$ シリーズ 


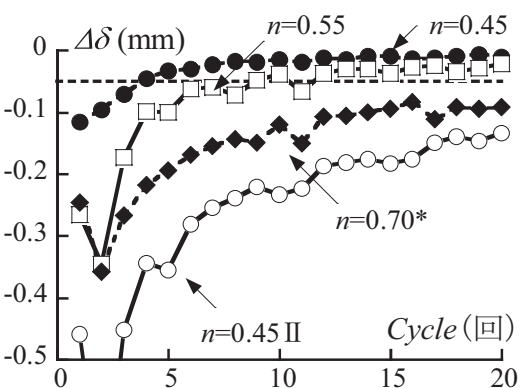

(a) L30 シリーズ

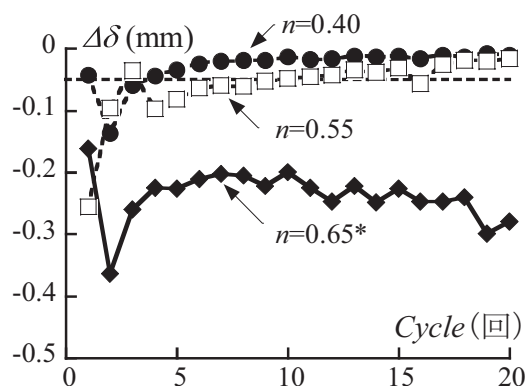

(b) L60 シリーズ

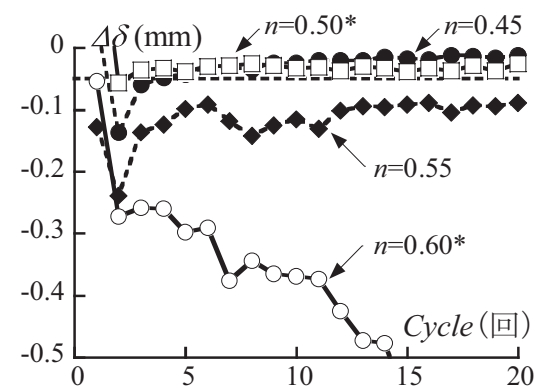

(c) $\mathrm{S} 60$ シリーズ

図 9 繰返しによる軸縮みの増分

表 4 安定限界軸力比

\begin{tabular}{|c|c|c|c|c|c|c|}
\hline 試験体名 & 軸力比 & $\begin{array}{c}\Delta \delta=0.05 \mathrm{~mm} \text { となる } \\
\text { Cycle数 (回) }\end{array}$ & $\begin{array}{c}\text { 収束軸縮み } \\
{ }_{1} \delta_{v}(\mathrm{~mm})\end{array}$ & $\begin{array}{c}\text { 圧壊軸縮み } \\
\delta_{c 0}(\mathrm{~mm})\end{array}$ & 判定 & $\begin{array}{l}\text { SRC規準の } \\
\text { 制限軸力比 }\end{array}$ \\
\hline L30-0.45 & 0.45 & 4 & -0.86 & -3.09 & 安定 & \multirow{3}{*}{0.50} \\
\hline L30-0.55 & 0.55 & 9 & -2.01 & -3.12 & 安定 & \\
\hline L30-0.70* & 0.70 & 無 & 無 & -3.15 & 不安定 & \\
\hline L60-0.40 & 0.40 & 4 & -0.87 & -2.70 & 安定 & \multirow{4}{*}{0.45} \\
\hline L60-0.50* & 0.50 & 8 & -1.60 & -2.73 & 安定 & \\
\hline L60-0.55 & 0.55 & 10 & -1.67 & -2.75 & 安定 & \\
\hline L60-0.65* & 0.65 & 無 & 無 & -2.78 & 不安定 & \\
\hline S60-0.40 & 0.40 & 4 & -0.89 & -2.65 & 安定 & \multirow{5}{*}{0.38} \\
\hline S60-0.45 & 0.45 & 5 & -0.95 & -2.66 & 安定 & \\
\hline S60-0.50* & 0.50 & 3 & -1.54 & -2.68 & 安定 & \\
\hline S60-0.55 & 0.55 & 無 & 無 & -2.70 & 不安定 & \\
\hline S60-0.60* & 0.60 & 無 & 無 & -2.72 & 不安定 & \\
\hline L30-0.45 II & 0.45 & $\begin{array}{l}\text { 無 } \\
\end{array}$ & $\begin{array}{ll}\text { 無 } \\
\end{array}$ & -2.86 & 不安定 & \multirow{2}{*}{0.47} \\
\hline L30-0.65 II * & 0.65 & 無 & 無 & -2.92 & 不安定 & \\
\hline
\end{tabular}

網掛けは各シリーズの安定限界軸力比を示す

から, SC 柱材の安定限界軸力は SRC 規準の制限軸力によって評価可 能である。なお，変位振幅 $R=2.0 \%$ は評価できていないため，振幅の 違いを考虑した安定限界軸力を定量的に検討した評価式については, 今後弾塑性解析を行った上で，別途報告する予定である。

\section{5. 弾塑性解析}

\section{1 解析モデル}

$\mathrm{SC}$ 柱材の弾塑性解析を行うため, 解析モデルを図 10 (a) に示すよ うな弾塑性ヒンジ部と剛体からなるものと考え, 柱材の変形を弾塑 性ヒンジ部に集中させ，その点での断面のモーメントー曲率関係を 求め, 力の釣合を満足させることにより, 柱の挙動を解析した。弾 塑性ヒンジ部での断面のモーメントー曲率関係は平面保持の仮定の もとで断面区分法により求めた。弾塑性ヒンジ部での曲率 $\phi$ と柱部 材角 $R$ の間に式(2) が成立つと仮定している。式(3) 中の $\alpha$ はSRC 柱 材の実験と解析の初期剛性を合わせることで求められた式である ${ }^{14)}$ 。 なお，式(2)，(3) を用いることで, 断面曲率と部材角の関係におい てせん断スパン比の違いによる影響を考慮している。また，文献 2) や14) において, せん断スパン比 $2 \sim 6$, 軸力比 $0 \sim 0.6$ の範囲で部 材角 $4.0 \%$ までの繰返し載荷した実験結果を, 本仮定のもとで求めた 解析結果で追跡できることを明らかとしている。

$$
\begin{aligned}
& R=\alpha \cdot L \cdot \phi \\
& \alpha=0.1+1.3 \frac{{ }_{c} D}{L}
\end{aligned}
$$

ここで, ${ }_{c}^{D}$ : 断面せいである。

\section{2 鉄骨の応力ー歪関係}

鋼材の応力ー歪関係は図 11 に示すモデルを用いた。鋼材の骨格
曲線は, 弾性域をヤング係数 $\mathrm{E}=2.05 \times 10^{5}\left(\mathrm{~N} / \mathrm{mm}^{2}\right)$ を勾配とした線形関係 で，降伏後はヤング係数 E の $1 / 100$ の勾配を持たせるバイリニア一型 のモデルとした。繰返しに伴う除荷後の挙動は, バウシンガー部の 構成則に加藤らの双曲線のモデル15) を用い, バウシンガー部の終点 の歪は山田らの提案式16) を用いた。ここで, 図中の $\Delta \varepsilon_{s k}$ : 鋼材の塑性 歪の増分, $\Delta \varepsilon_{b s}$ : 鋼材のバウシンガー部における塑性歪の増分である。 5.3 コンクリートの応カー歪関係

コンクリートの応力ー歪関係は崎野孫モデル13)を使用した。ただ し，コンクリートの構成則は SC 柱材の中心圧縮実験から得られた成 果を元 ${ }^{3)}$ に，十字鉄骨によるコンクリートの拘束効果を考慮し，十 字鉄骨の内側と外側に分割して求めている。なお, 繰返し則は渡辺 らのモデル17)を用いた（図 12 参照)。材料の応力一歪関係について の詳細は文献 3) を参照されたい。

本実験では $60 \mathrm{~N} / \mathrm{mm}^{2}$ 級の高強度コンクリート及び鉄骨比 $2.7 \%$ の小 さな十字鉄骨を内蔵している。そこで, 文献 3) で示した解析手法が 適用可能であるかを検証するために中心圧縮実験を行い, 上述した 条件下における SC 断面のコンクリートの構成則について検討した。 試験体は表 1 で示した L60 と S60 シリーズの各一体ずつで，実験 時のコンクリート強度は $53.7 \mathrm{~N} / \mathrm{mm}^{2}$, 材長は $600 \mathrm{~mm}$ である。載荷装置 を図 13 に示す。文献 3 ) と同様に, 載荷方法は鋼管及び内蔵鉄骨に 圧縮力を負担させないようにしてコンクリートのみを圧縮した。圧 縮力は $5000 \mathrm{kN}$ 万能試験機で載荷し, 軸変形は加圧板間の全体変形 $600 \mathrm{~mm}$ を 4 箇所に設置した変位計で測定した。

実験結果と解析結果の比較を図 14 に示寸。L60 は文献3) で示し た解析手法とよく対応している。鉄骨の負担軸力を降伏後は一定と して全体荷重からコンクリートの負担軸力を算出しているが，変位 $4 \mathrm{~mm}$ 以降での耐力上昇は鉄骨の歪硬化によるものだと考えられる。 一方で，S60 は危険側の評価となっている。この理由として，S60は 内蔵十字鉄骨比が $2.7 \%$ と小さいことから, 十字鉄骨外の鋼管で拘束 されたコンクリートは鉄骨ウェブによる効果を受けられず，鋼管の みで拘束された状態にあると考えることができる(図 15 参照)。そこ で，十字鉄骨外側のコンクリートを鋼管のみによる拘束で，十字鉄 骨内側のコンクリートは文献 3) で示した拘束効果を考慮して解析を 行うと精度よく評価した。よって, S60 シリーズの弾塑性解析では上 述した構成則に従い解析を行う。

\section{4 実験挙動と解析結果の比較}

図 16 , 図 17 及び表 5 に実験挙動と解析結果の比較を示寸。解析 では断面の中心軸歪 $\varepsilon_{0}$ を計算しているが, 式(2)で考えた $\alpha L$ は図 10(b) に示すように変形域長さと捉えることもできると考えられるので, その值を用いて変形域と弾性域(図 10(b) 参照) の変形を考慮して式(4) 
により軸縮み $\delta_{v}$ に変換している。なお, 軸方向変形については図 10(b) に示寸モデルを考え, 図 10(b) 中の弾性域は軸方向に対して弾性であ り, 変形域は $\varepsilon_{0}$ が材長方向に一様に分布すると考えた領域である。 また, 再載荷した試験体の解析は実験条件と同様に 20 回の繰返し水 平力を載荷した後, 一度軸力を抜いて所定の軸力を載荷して再び繰 返し水平力を与える解析を行った。ここで, 残留変形点は変位振幅 $R=1.0 \%$ の試験体では残留部材角が $0 \%$ に近かったことを考慮して, 解析では部材角 $0 \%$ から再載荷を行った。 $R=2.0 \%$ の試験体は水平力 $0 \mathrm{kN}$ から再載荷を行っている。

$$
\begin{aligned}
& \delta_{v}=2\left(\alpha L \varepsilon_{0}+\frac{N(L-\alpha L)}{{ }_{s} E_{s} A+{ }_{c} E_{c} A}\right) \\
& { }_{c} E=3.35 \times 10^{4} \times\left(\frac{\gamma}{24}\right)^{2} \times\left(\frac{{ }_{c} \sigma_{B}}{60}\right)^{\frac{1}{3}} \quad\left(\mathrm{~N} / \mathrm{mm}^{2}\right)
\end{aligned}
$$

ここで, ${ }_{s} E$ : 鉄骨のヤング係数, $E$ ：コンクリートのヤング係数, $\gamma$ : コンクリートの単位容積重量 $\left(\mathrm{kN} / \mathrm{m}^{3}\right)$ である。

図 16.1, 図 16.2 (以下図 16 と略) 及び表 5 より, 最大水平耐力は実験 值の方が大きな值を示している。これは，1) 十字鉄骨によるコンク リートの拘束効果を解析手法がやや安全側の評価となるように評価 していること，2) 上下スタブの拘束により, 実験では破壊領域が固 定端よりも内側に形成されること, が考えられる。これに伴い, 初 期岡性の評価もやや実験值の方が大きくなっているが，再載荷した 試験体については初期剛性が小さな值を取る傾向が見られた。図 17.1 及び図 17.2 (以下図 17 と略) より, 軸縮みは軸力比が安定限界軸 力比以下であると実験值が大きめの值となっているが，これは実験 ではサイクル毎の除荷時に加力を保持したまま試験体の観察を行っ ており, この間に軸縮みが蓄積されたこと, またスタブと鋼管の上 下 $10 \mathrm{~mm}$ 区間の隙間で縮みが見られたことも要因であると考えられ

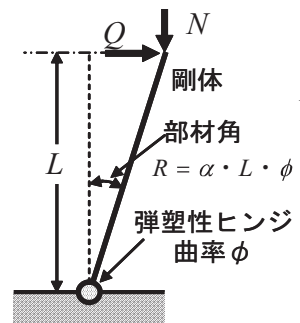

(a) 解析モデル (b) 軸方向変形の考え方

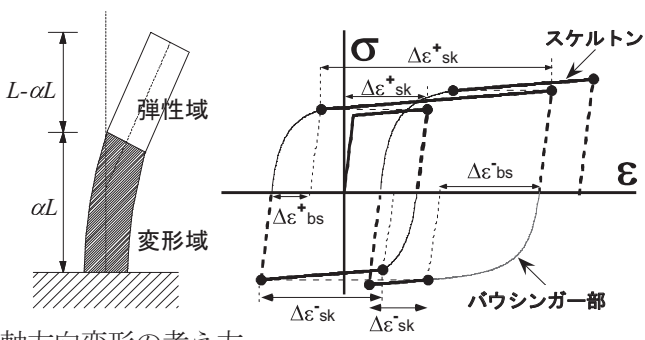

図 11 鋼材の応力一歪関係

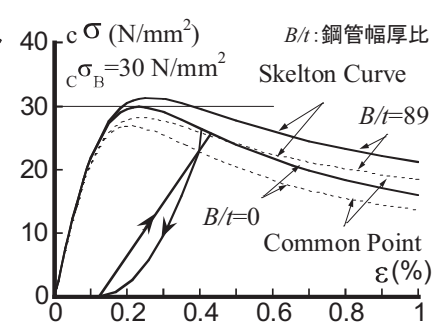

図 12 コンクリートの繰返し則

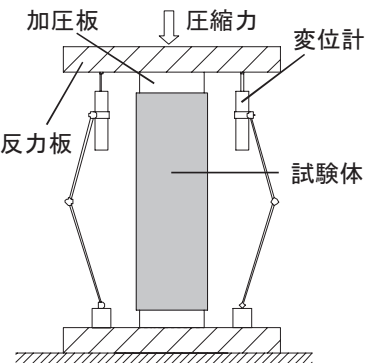

図 13 載荷装置

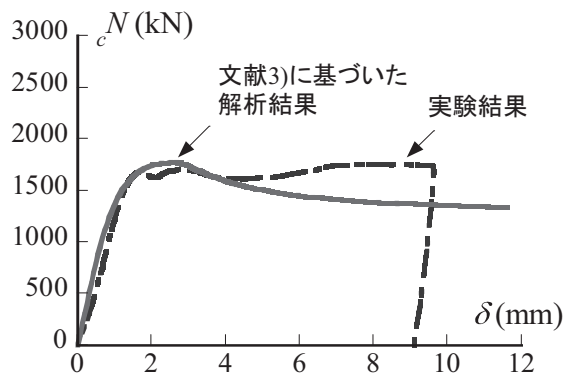

(a) L60 シリーズ

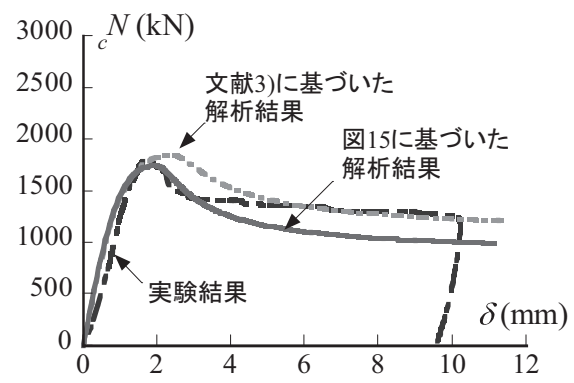

(b) S60 シリーズ

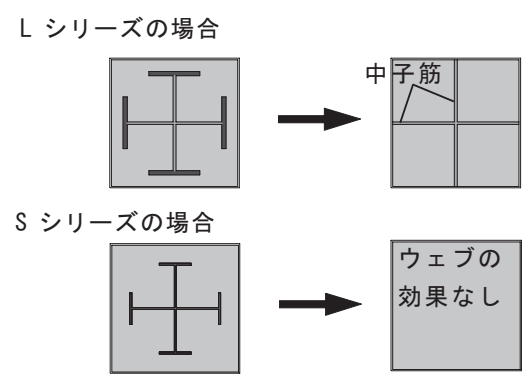

図 15 十字鉄骨外の鋼管で拘束された コンクリートの拘束効果

図14 中心圧縮実験結果と解析結果の比較

\begin{tabular}{|c|c|c|c|c|c|c|c|c|c|c|c|c|c|c|c|}
\hline \multirow[b]{2}{*}{ 試験体名 } & \multicolumn{5}{|c|}{ 実験結果 } & \multicolumn{5}{|c|}{ 解析結果 } & \multicolumn{5}{|c|}{ 実験結果/解析結果 } \\
\hline & $\begin{array}{c}\text { ex } Q_{\max } \\
(\mathrm{kN})\end{array}$ & $\begin{array}{l}\operatorname{ex}_{20} \\
(\mathrm{kN})\end{array}$ & $\begin{array}{c}\text { ex } \mathrm{K}_{0.2} \\
(\mathrm{kN})\end{array}$ & $\begin{array}{c}\text { ex } \mathrm{K}_{0.5} \\
(\mathrm{kN})\end{array}$ & $\begin{array}{l}e^{e x} \delta_{\mathrm{v} 20} \\
(\mathrm{~mm})\end{array}$ & $\begin{array}{c}{ }_{a n} Q_{\max } \\
(\mathrm{kN})\end{array}$ & $\begin{array}{c}{ }_{a n} Q_{20} \\
(\mathrm{kN})\end{array}$ & $\begin{array}{c}{ }_{\text {an }} \mathrm{K}_{0.2} \\
(\mathrm{kN})\end{array}$ & $\begin{array}{r}{ }_{\text {an }} \mathrm{K}_{0.5} \\
(\mathrm{kN})\end{array}$ & $\begin{array}{l}\text { an } \delta_{\mathrm{v} 20} \\
(\mathrm{~mm})\end{array}$ & $\begin{array}{l}e^{{ }_{x} Q_{\max }} \\
\text { an } Q_{\max }\end{array}$ & $\begin{array}{c}e^{e x} Q_{20} \\
\text { an } Q_{20}\end{array}$ & $\begin{array}{c}\mathrm{ex}^{\mathrm{ex}} \mathrm{K}_{0.2} \\
{ }_{\mathrm{an}} \mathrm{K}_{0.2}\end{array}$ & $\begin{array}{l}\text { ex } \mathrm{K}_{0.5} \\
{ }_{n} \mathrm{~K}_{0.5}\end{array}$ & $\begin{array}{l}e^{e x} \delta_{\mathrm{v} 20} \\
\text { an } \delta_{\mathrm{v} 20}\end{array}$ \\
\hline L30-0.45 & 178.6 & 150.0 & 35759 & 24407 & -1.11 & 144.6 & 141.4 & 32101 & 21718 & -0.84 & 1.24 & 1.06 & 1.11 & 1.12 & 1.31 \\
\hline L30-0.55 & 175.2 & 152.1 & 38186 & 23758 & -2.39 & 145.0 & 140.4 & 32603 & 21200 & -2.02 & 1.21 & 1.08 & 1.17 & 1.12 & 1.18 \\
\hline L30-0.70* & 162.0 & 151.6 & 18355 & 16497 & -4.86 & 126.7 & 無 & 16547 & 17466 & 無 & 1.28 & 無 & 1.11 & 0.94 & 無 \\
\hline L60-0.40 & 213.7 & 174.0 & 51968 & 33699 & -1.13 & 196.2 & 189.8 & 45813 & 30433 & -0.65 & 1.09 & 0.92 & 1.13 & 1.11 & 1.73 \\
\hline L60-0.50* & 183.3 & 171.2 & 21650 & 19428 & -2.04 & 194.3 & 190.7 & 23094 & 20947 & -1.28 & 0.94 & 0.90 & 0.94 & 0.93 & 1.59 \\
\hline L60-0.55 & 223.6 & 196.1 & 52927 & 28097 & -2.00 & 191.5 & 179.8 & 46427 & 29731 & -2.33 & 1.17 & 1.09 & 1.14 & 0.95 & 0.86 \\
\hline L60-0.65* & 181.1 & 168.2 & 20408 & 18216 & -7.28 & 174.2 & 無 & 23768 & 26034 & 無 & 1.04 & 無 & 0.86 & 0.70 & 無 \\
\hline S60-0.40 & 170.3 & 134.0 & 42109 & 25868 & -1.15 & 129.9 & 126.7 & 38074 & 22853 & -0.56 & 1.31 & 1.06 & 1.11 & 1.13 & 2.04 \\
\hline S60-0.45 & 159.8 & 131.5 & 42822 & 26811 & -1.31 & 126.3 & 122.3 & 37395 & 22620 & -0.81 & 1.27 & 1.08 & 1.15 & 1.19 & 1.61 \\
\hline S60-0.50* & 137.6 & 128.0 & 20896 & 16642 & -2.09 & 128.6 & 121.7 & 27000 & 18426 & -1.28 & 1.07 & 1.05 & 0.77 & 0.90 & 1.64 \\
\hline S60-0.55 & 183.8 & 127.3 & 42062 & 28643 & -3.19 & 121.9 & 101.9 & 36956 & 22766 & -4.92 & 1.51 & 1.25 & 1.14 & 1.26 & 0.65 \\
\hline S60-0.60* & 158.6 & 無 & 24543 & 20786 & 無 & 119.4 & 無 & 30981 & 21281 & 無 & 1.33 & 無 & 0.79 & 0.98 & 無 \\
\hline L30-0.65 II * & 174.3 & 無 & 13030 & 11621 & 無 & 148.8 & 無 & 13699 & 12191 & 無 & 1.17 & 無 & 0.95 & 0.95 & 無 \\
\hline
\end{tabular}

表 5 実験結果と解析結果の比較

$\mathrm{Q}_{\max }$ : 最大水平耐力, $\mathrm{Q}_{20}: 20$ 回目の水平耐力, $\mathrm{K}_{0.2}: R=0.2 \%$ 時の割線岡性, $\mathrm{K}_{0.5}: R=0.5 \%$ 時の割線剛性, $\delta_{v 20}: 20$ 回目の軸縮み, ex : 実験結果, an : 解析結果 


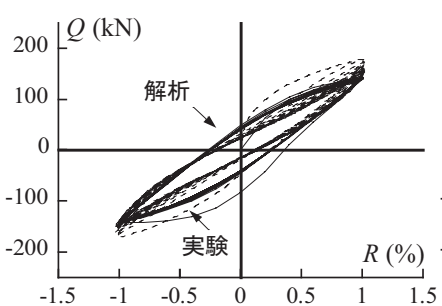

(a) $\mathrm{L} 30-0.45$

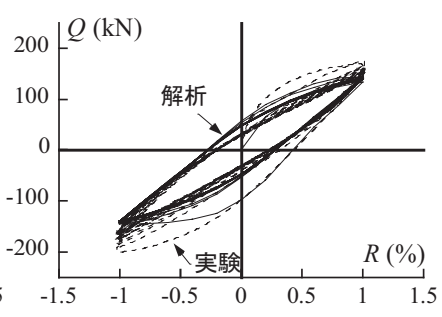

(b) $\mathrm{L} 30-0.55$

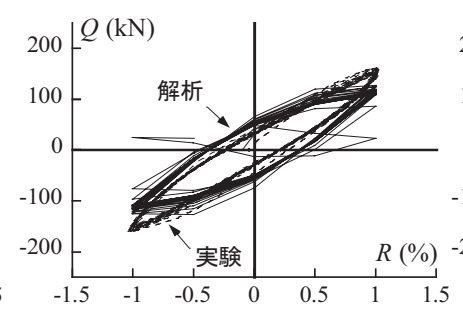

(c) $\mathrm{L} 30-0.70 *$

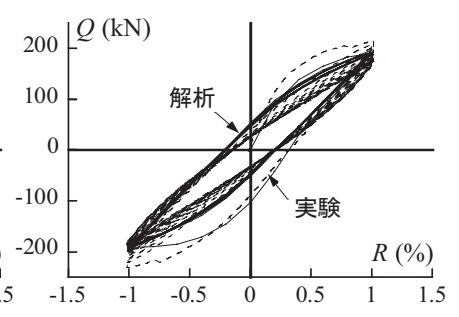

(d) $\mathrm{L} 60-0.40$

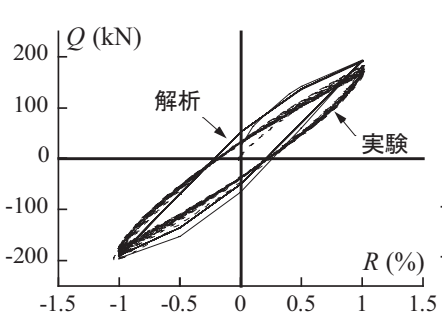

(e) $\mathrm{L} 60-0.50 *$

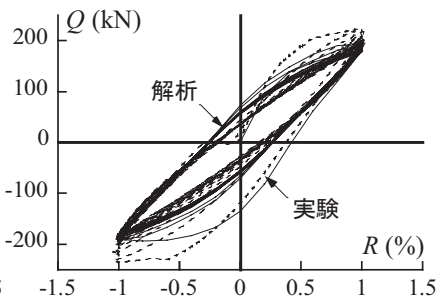

(f) L60-0.55

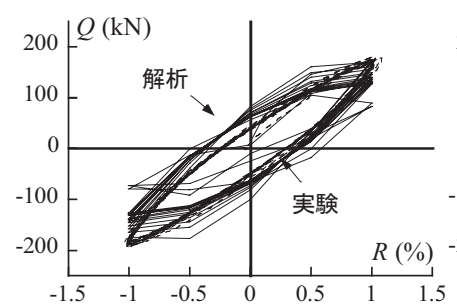

(g) L60-0.65*

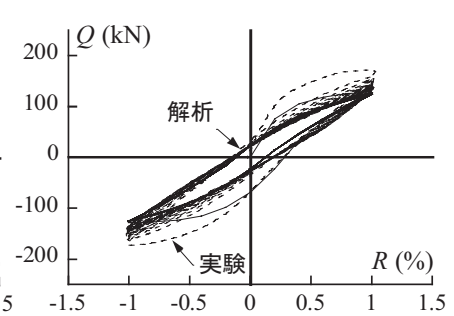

(h) $\mathrm{S} 60-0.40$

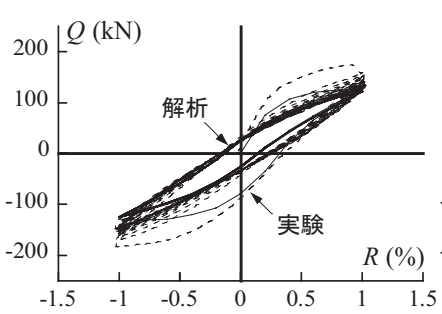

(i) $\mathrm{S} 60-0.45$

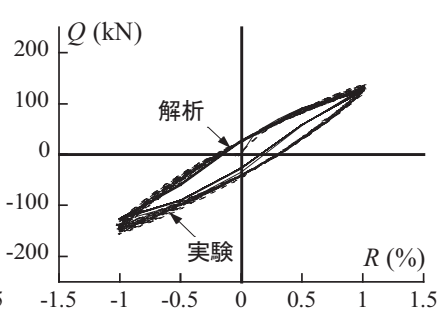

(j) S60-0.50*

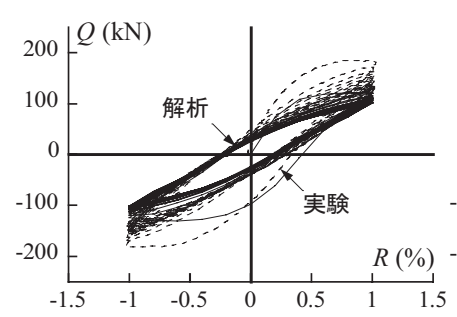

(k) S60-0.55

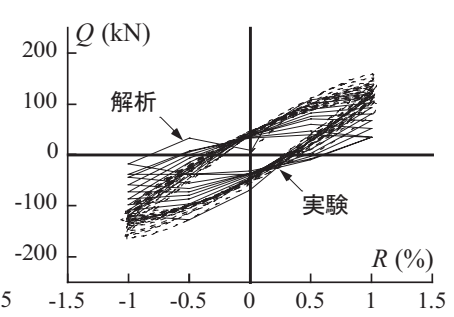

(1) $\mathrm{S} 60-0.60 *$

* は再載荷した試験体を示す

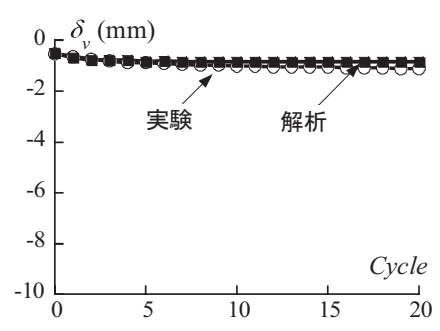

(a) L30-0.45

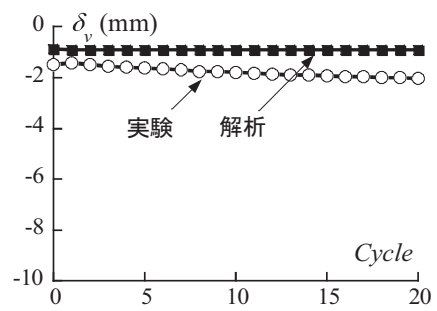

(e) $\mathrm{L} 60-0.50 *$

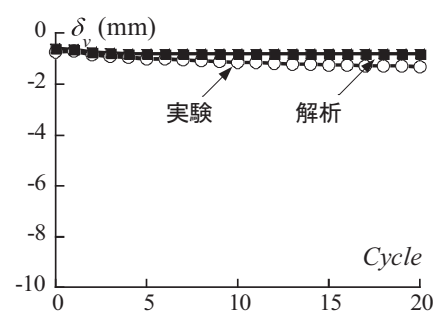

(i) $\mathrm{S} 60-0.45$

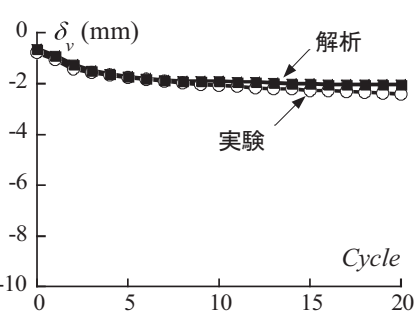

(b) $\mathrm{L} 30-0.55$

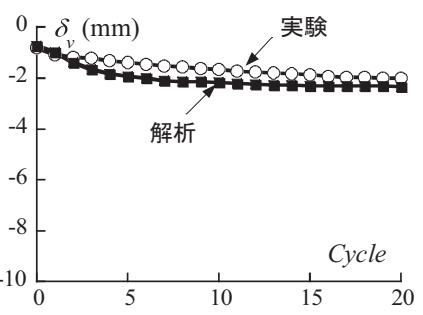

(f) L60-0.55

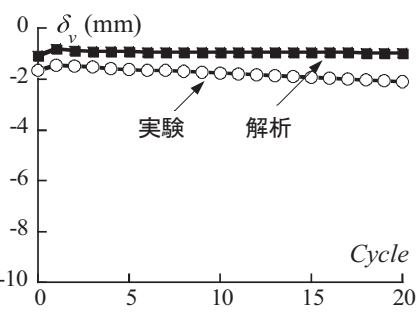

(j) $\mathrm{S} 60-0.50 *$

図 17.1 軸縮み $\delta_{v}$-Cycle 関係（振幅 $R=1.0 \%$, つづく）

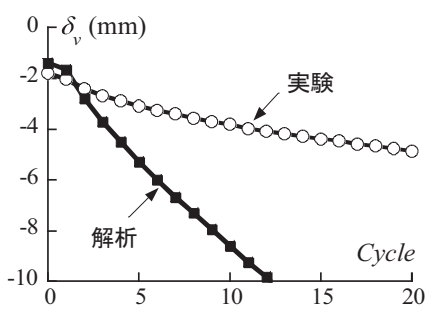

(c) $\mathrm{L} 30-0.70 *$

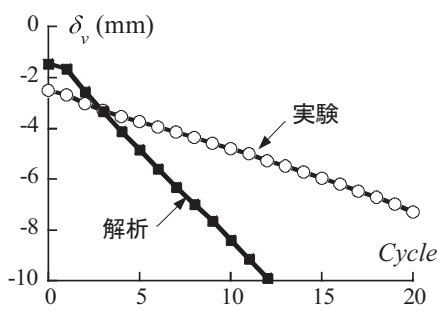

(g) $\mathrm{L} 60-0.65 *$

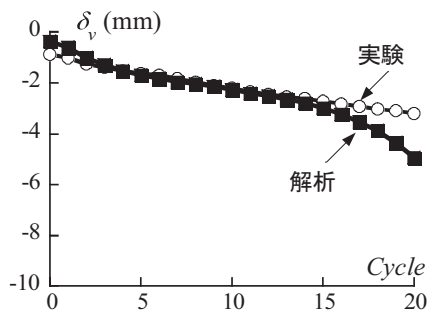

(k) S60-0.55

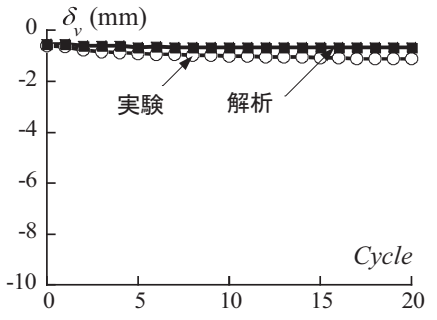

(d) $\mathrm{L} 60-0.40$

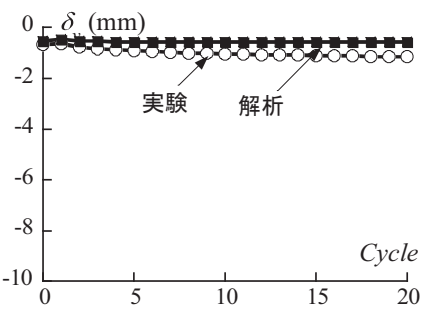

(h) $\mathrm{S} 60-0.40$

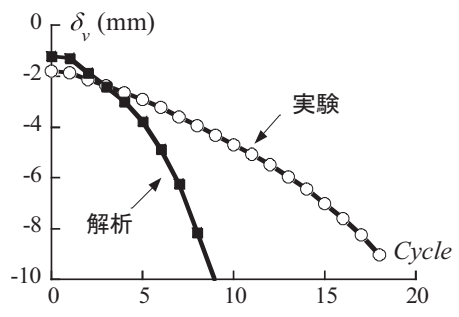

(1) $\mathrm{S} 60-0.60 \%$

*は再載荷した試験体を示す 


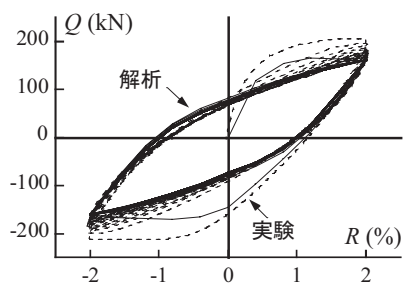

(m) L30-0.45 II

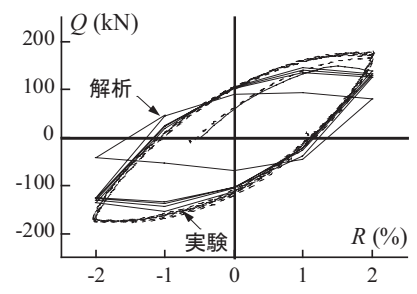

(n) L30-0.65 II *
図 16.2 水平力 $Q-$ 部材角 $R$ 関係の比較（振幅 $R=2.0 \%$, つづき）

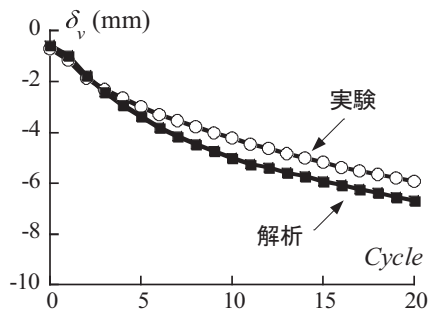

(m) L30-0.45 II

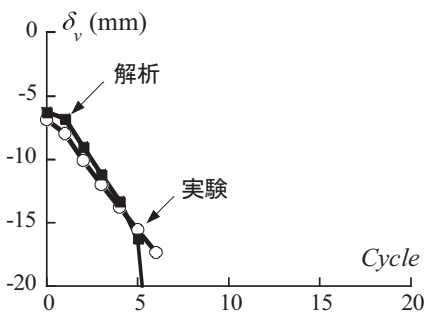

(n) $\mathrm{L} 30-0.65 \mathrm{II} *$
図 17.2 軸縮み $\delta_{v}-$ Cycle 関係の比較（振幅 $R=2.0 \%$,つづき）

る。加えて，再載荷した試験体（(e)L60-0.50*及び(j)S50-0.50*) では実 験值の方が軸縮み量が大きくなったが，これは初期歪に違いが見ら れることが原因である。一方で，圧壊歪を超えるような試験体では 解析值の方が大きな值となっている。(1)S60-0.55 や(m)L30-0.45 II のよ うに圧壊歪を超えるような軸力比では軸縮みが実験值を安全側に評 価することを考慮すると, 安定限界軸力比を本解析手法で評価する ことは可能であるものと考えられる。また，振幅 $R=2.0 \%$ の試験体で は安定限界軸力比を見つけ出すことはできなかったが，(m)L30-0.45 II の実験と解析の軸縮みの進行の比較を見ると精度よく追跡できて いることが分かる。総じて，最大水平耐力は過大評価となる傾向が 見られたが，20回目の水平耐力の平均值は 1.05 と良好である。また， 軸縮みの進行も概ね追跡できていることから本解析手法の精度は最 大耐力や再載荷後の初期歪の整合性といった検討の余地もあるが, 概ね良好である。

\section{6. 結論}

薄肉鋼管で横補強した鋼・コンクリート合成柱材の安定限界軸力 について検討した結果，以下のことが明らかとなった。

1）軸力比を変化させて実験を行ったところ, 中心軸歪の進行がなく なり，ほぼ一定值に収束する軸力が存在する。

2）実験結果の考察より，収束する中心軸歪が十字鉄骨内側のコンク リートの圧壊歪を超えていなければ安定であるとし，このときの 最大軸力を安定限界軸力と定義した。

3）部材角 $R=1.0 \%$ 及び $2.0 \%$ の変形における安定限界軸力の曲げ耐力に ついて，最大曲げ耐力は材料強度を用いて計算した $M_{p c l}$ で，定変 位振幅で多数回繰返し水平力を受ける過酷な条件下でも曲げ耐力 はコンクリートの低減係数 ${ }_{c} \gamma_{U}$ を用いて計算した $M_{p c 2}$ を確保でき る。

4) 本論で定義した安定限界軸力によると, 鉄骨比が大きい断面でコ ンクリート強度 $\sigma_{i}=30 \mathrm{~N} / \mathrm{mm}^{2}, 60 \mathrm{~N} / \mathrm{mm}^{2}$ を使用した場合, 安定限界 軸力比は双方とも $n=0.55$ 程度であり，鉄骨比の小さい断面では $n=0.50$ 程度であった。また， $R=1.0 \%$ で $\mathrm{SC}$ 柱材の安定限界軸力は $\mathrm{SRC}$ 規準で規定されている制限軸力で評価できることを示した。

5) 変位振幅 $R=2.0 \%$ の実験では安定限界軸力を見つけることはできな かつたが，実験挙動の軸縮みの進行を解析結果で精度よく評価で きていることから，今後弾塑性解析を行うことで変位振幅の違い が柱材の安定限界軸力に及ぼす影響を定量的に検討する。

6 ）本論で提案した解析手法は，実験結果における繰返しに伴う軸縮 みの進行を精度よく追跡できている。

\section{謝辞}

本研究に関して，九州大学河野昭彦教授並びに北九州市立大学津 田恵吾教授に貴重なご助言を頂いた。載荷実験実施にあたり研究当 時福岡大学堺研究室の山本洋平氏（現竹中工務店）にご協力頂いた。 また, 平成 $21 \sim 23$ 年度科学研究費補助金(基礎研究 (c), 研究代表者: 堺純一) の助成を受けた。ここに記して感謝の意を表します。

\section{参考文献}

1）堺純一, 河本 裕行, 松原佳毅 : 横補強鋼管を用いた鋼コンクリート合成 柱材の弾塑性変形性状に関する実験的研究, 構造工学論文集, Vol. 53 , pp.383-388, 2007.3

2）倉富洋，堺純一，田中照久，河本裕行：薄肉鋼管で横補強した鋼・コンク リート合成柱材の復元力特性 - 骨格曲線の定式化 - , 日本建築学会構造系 論文集，Vol.673，pp.491-498，2012.3

3）倉富洋，堺純一，田中照久，河本裕行：薄肉鋼管で横補強した鋼・コンク リート合成柱材の弾塑性性状に関寸る研究，構造工学論文集，Vo1.57， pp.527-534, 2011.3

4）倉富洋, 堺純一, 田中照久, 河本裕行 : 薄肉鋼管で横補強した鋼コンクリー 卜合成柱材の構造性能及び安定限界軸力に関寸る研究，コンクリート工学 年次論文集, Vol.33, No. 2, pp.1129-1134, 2011.7

5）倉富洋, 堺純一, 田中照久, 河本裕行 : 鋼コンクリート合成柱材の安定限 界軸力に関する実験的研究，日本建築学会九州支部研究報告，第 51 号， pp.725-728, 2012.3

6）崎野健治, 田福勝, 孫玉平, 大庭央久： $\mathrm{RC}$ 柱の安定限界軸力比に及ぼす横 補強筋の影響, コンクリート工学年次論文集, Vol.20, No.3, pp.499-504, 1998

7）平石久廣，稲井栄一，薬研地彰：繰返し載荷を受ける鉄筋コンクリート造 柱の限界変形, 日本建築学会構造系論文報告集, Vol.454, pp.127-138，1993.12

8）松井千秋, 江冠華, 夏木美智子 : SRC 柱材の安定限界軸力に関する実験的 研究，日本建築学会九州支部研究報告，第32 号，pp.225-228，1991.3

9）松井千秋, 津田恵吾, 江冠華 : 繰返し曲げを受ける SRC 柱材の安定限界軸 力に関する解析的研究，コンクリート工学論文集，第 3 巻 1 号，pp.45-55, 1992.1

10）土井希祐, 片寄哲務: 変動軸力を受ける SRC 柱部材の静加力実験, 日本建 築学会大会学術講演梗概集，構造III，pp.1089-1090，2000.9

11) 爱河知紀, 寺井雅和, 南宏一: 変動軸力を受ける実大 SPRC 柱の弾塑性挙動 に関する基礎的研究，日本建築学会大会学術講演梗概集，構造系 (C-2), pp.331-332, 2002.8

12）日本建築学会 : 鉄骨鉄筋コンクリート構造計算規準・同解説，2001.1

13 ) 崎野健治, 孫玉平: 直線型横補強材により拘束されたコンクリートの応力 一ひず夕関係，日本建築学会構造系論文集，Vol.461，pp.95-104，1994.7

14）堺純一，松井千秋：鉄骨鉄筋コンクリート柱材の復元力特性に関する研究 一単一 $\mathrm{H}$ 形鋼を内蔵した SRC 柱の骨格曲線の定式化一, 日本建築学会構造 系論文集，Vol.534，pp.183-190，2000.8

15 ) 加藤勉，秋山宏，山内泰之 : 鋼材の応力ーひずみ履歴曲線に関する実験則, 日本建築学会大会学術講演梗概集, pp.937-938, 1973.10

16）山田哲，今枝知子，岡田健：バウシンガー効果を考慮した構造用鋼材の簡 潔な履歴モデル，日本建築学会構造系論文集，第 559 号，pp.225-232，2002.9

17 ) 鎌田圭次郎，大住和正，渡辺史夫，六車熙：各種強度の鉄筋混使用による $\mathrm{RC}$ 断面曲 性能の制御，日本建築学会大会学術講演梗概集，構造 II B pp.505-506, 1991.9 